\title{
Effect of Bentonite Characteristics on the Elemental Composition of Wine
}

\author{
Sofia Catarino, ${ }^{*},+*$ M. Madeira,${ }^{\S}$ F. Monteiro, ${ }^{\S}$ F. Rocha,${ }^{\Delta}$ \\ A. S. Curvelo-Garcia, ${ }^{\dagger}$ And R. Bruno de Sousa ${ }^{*}$ \\ Estação Vitivinícola Nacional, 2565-191 Dois Portos, Portugal, Universidade Técnica de Lisboa, \\ Instituto Superior de Agronomia, Departamento de Química Agrícola e Ambiental, Tapada da Ajuda, \\ 1349-017 Lisboa, Portugal, Universidade Técnica de Lisboa, Instituto Superior de Agronomia, \\ Departamento de Ciências do Ambiente, Tapada da Ajuda, 1349-017 Lisboa, Portugal, and \\ Universidade de Aveiro, Departamento de Geociências, Campus Universitário de Santiago,
} 3810-193 Aveiro, Portugal

\begin{abstract}
Physical, chemical, and mineralogical characteristics of six bentonites were assessed and related to their elemental release to wine. Extraction essays of bentonites in wine at three $\mathrm{pH}$ levels were carried out. The multielemental analysis of bentonites and wines was performed by atomic absorption spectrometry (AAS) and inductively coupled plasma mass spectrometry (ICP-MS). Bentonite addition resulted in significantly higher concentrations of $\mathrm{Li}, \mathrm{Be}, \mathrm{Na}, \mathrm{Mg}, \mathrm{Al}, \mathrm{Ca}, \mathrm{Sc}, \mathrm{V}, \mathrm{Mn}, \mathrm{Fe}, \mathrm{Co}, \mathrm{Ni}, \mathrm{Ga}$, $\mathrm{Ge}, \mathrm{As}, \mathrm{Sr}, \mathrm{Y}, \mathrm{Zr}, \mathrm{Nb}, \mathrm{Mo}, \mathrm{Cd}, \mathrm{Sn}, \mathrm{Sb}, \mathrm{Ba}, \mathrm{W}, \mathrm{Tl}, \mathrm{Bi}$, and W. In contrast, the concentrations of $\mathrm{B}, \mathrm{K}$, $\mathrm{Cu}, \mathrm{Zn}$, and $\mathrm{Rb}$ significantly decreased. A strong correlation between $\mathrm{Na}$ concentrations of treated wines and its content in bentonite exchange complex was observed. Al and Fe contents reflected bentonite extractable aluminous and ferruginous constituents, while $\mathrm{Be}, \mathrm{Mg}, \mathrm{Ca}, \mathrm{V}, \mathrm{Mn}, \mathrm{Ni}, \mathrm{Ge}, \mathrm{Zr}$, $\mathrm{Nb}, \mathrm{Mo}, \mathrm{Sn}, \mathrm{Sb}, \mathrm{TI}, \mathrm{Pb}$, and $\mathrm{U}$ concentrations reflected the elemental composition of bentonites. Several nonconformances with OIV specifications demonstrated the need for an effective control.
\end{abstract}

KEYWORDS: Contaminant elements; wine; bentonite physical and chemical characteristics; ICP-MS

\section{INTRODUCTION}

Bentonite is a technological aid widely used in winemaking to remove or reduce the concentration of undesirable constituents. In particular, it acts as a settling aid to remove proteins, thus reducing the risk of protein haze in wine, whose occurrence could compromise its acceptance by the consumer. Because of its mineral nature, bentonite treatment agent highly influences the final wine elemental composition (1-3).

Bentonite is the commercial designation of an expansive clay material mainly composed by montmorillonite $(4,5)$. In addition to montmorillonite, bentonite could contain quartz, chalcedony, feldspars, calcite, dolomite, analcime, and pyrite, among others, as accessory minerals. Montmorillonite is a 2:1 dioctahedral smectite whose structure consists of two tetrahedral silicon oxide sheets and one octahedral aluminum hydroxide sheet, combined as a crystalline structural layer unit. Ideally, in the structure of montmorillonite, some $\mathrm{Al}^{3+}$ in octahedral positions is displaced

* Corresponding author. E-mail evn.sofia.catarino@mail.net4b.pt. Telephone: +351 261712106. Fax: +351 261712426.

${ }^{\dagger}$ Estação Vitivinícola Nacional.

* Universidade Técnica de Lisboa, Instituto Superior de Agronomia, Departamento de Química Agrícola e Ambiental.

${ }^{\S}$ Universidade Técnica de Lisboa, Instituto Superior de Agronomia, Departamento de Ciências do Ambiente.

${ }^{\triangle}$ Universidade de Aveiro, Departamento de Geociências. by $\mathrm{Mg}^{2+}, \mathrm{Fe}^{2+}$, and $\mathrm{Fe}^{3+}$ as well as by other divalent cations, leading to charge imbalances (6). The negative surface charge is mostly permanent and ranges from -0.2 to $-0.6(Z)$ formula unit (7). In addition, its structure also shows variable surface charge located in the $\mathrm{OH}$ groups forwhich signal and intensity is a function of solution $\mathrm{pH}$ value (8). The negative charge is balanced by exchangeable cations localized within the interlayer space or on the external surface of the clay particles. These cations are mainly $\mathrm{Ca}^{2+}, \mathrm{Na}^{+}$, and $\mathrm{Mg}^{2+}$, but other cations such as $\mathrm{K}^{+}, \mathrm{Fe}^{2+}$, and $\mathrm{Cu}^{+}$are present to a minor extent (9). Both major and minor cations ratio can significantly vary from one bentonite to another.

Bentonite nature can be changed through activation treatment, often employed on natural Ca bentonites (high $\mathrm{Ca}^{2+} / \mathrm{Na}^{+}$ratio). The activation process consists of a treatment of the wet mud by solid $\mathrm{Na}_{2} \mathrm{CO}_{3}$ at a temperature of $80{ }^{\circ} \mathrm{C}$ in order to obtain similar properties to natural $\mathrm{Na}$ bentonites (high $\mathrm{Na}^{+} / \mathrm{Ca}^{2+}$ ratio), which have enhanced protein binding ability $(10,11)$. For this reason, bentonites are classified according to the function of exchangeable cations into three categories: natural $\mathrm{Na}$ bentonites, natural $\mathrm{Ca}$ bentonites, and activated $\mathrm{Ca}$ bentonites.

The adsorption of positively charged proteins and other soluble cationic constituents by bentonites in the wine is primarily due to the cationic exchange properties of these clays. The adsorption of protein is affected through competition from other cations in the solution matrix and also affected by $\mathrm{pH}$ 
Table 1. Bentonites Used in Extraction Essays

\begin{tabular}{cll}
\hline code & \multicolumn{1}{c}{ form } & \multicolumn{1}{c}{ type } \\
\hline B1 & fine powder & activated $\mathrm{Ca}$ \\
B3 & granule & $\mathrm{Na}$ \\
B4 & granule & $\mathrm{Na}$ \\
B5 & powder & activated $\mathrm{Ca}$ \\
B8 & elongated filament & $\mathrm{Na}$ \\
B9 & stony granule & $\mathrm{Na}$
\end{tabular}

and ethanol content of solution (10). Competition would be from $\mathrm{K}^{+}, \mathrm{Ca}^{2+}, \mathrm{Mg}^{2+}, \mathrm{Na}^{+}$, and $\mathrm{H}^{+}$, most amino acids, some peptides, and other cationic fractions. A study developed by Blade and Boulton (10), concerning several potential affecting factors, showed that protein adsorption was independent of temperature but varied with protein and ethanol contents and $\mathrm{pH}$ value.

The effects of bentonite addition to wine have been mostly studied in order to assess the depletion of proteins, amino acids, bioamines, polyphenols, and aroma compounds (12-15). Some studies concerning the variation of major elements concentrations ( $\mathrm{Na}, \mathrm{Ca}, \mathrm{Mg}$ ) and also $\mathrm{Al}, \mathrm{Fe}, \mathrm{Mn}, \mathrm{Cr}$, and $\mathrm{Pb}$ when bentonites are used as fining agents have also been developed $(1,3,14,16,17)$. Additionally, decreases of $\mathrm{K}, \mathrm{Cu}, \mathrm{Zn}$, and $\mathrm{Rb}$ concentrations in wine were reported $(3,14,18)$. Meanwhile, there is not complete agreement among reported data, probably owing to different experimental conditions. Despite that, the results suggested a relationship between bentonite characteristics and elemental release.

Significant increases of micro and trace elements in treated wine were reported $(3,19)$. Moreover, Jakubowski et al. (2) reported that the concentration pattern of the rare earth elements can be strongly affected by bentonite treatment and therefore is not suitable as a fingerprint for the provenance of wines.

Although origin, type, and label variety of bentonites on the market are considerable, a general chemical and structural characterization and application instructions are usually supplied. However, no information on the potential mineral release to wine is given. To date, the International Organization of Vine and Wine (OIV) defines a minimum content of montmorillonite and maximum contents for extractable $\mathrm{Pb}, \mathrm{Hg}, \mathrm{As}, \mathrm{Fe}, \mathrm{Al}, \mathrm{Na}$, and combined $\mathrm{Ca}$ and $\mathrm{Mg}$ (5).

From an oenological point of view, the composition and structure of bentonites have been studied and related to their protein adsorption capacities (4, 9, 20-22). Nevertheless, similar studies regarding micro and trace elements release to wine have not been done so far except for those of rare earth elements $(2,23,24)$.

Thus, a study was carried out to evaluate the release of contaminant elements from several bentonites to wine, and to understand the effects of their physical and chemical characteristics.

\section{MATERIALS AND METHODS}

Bentonite Characteristics. Six different bentonites (B1, B3, B4, B5, B8, and B9) supplied by four companies (in Portugal) were used in the extraction essays (Table 1). Previously, some physical and chemical characteristics were assessed to obtain more precise information on the studied bentonites. For that, each material was forced to pass through a sieve of $2 \mathrm{~mm}$. Particle size fractions were determined as described by Póvoas and Barral (25). Organic carbon content was determined by wet oxidation, by the Springer and Klee method, following the methodology modified and reported by Póvoas and Barral (25). Values of $\mathrm{pH}$ were measured in water (bentonite to water ratio 1:2.5) using a pH meter Metrohm 632. Cation exchange capacity and exchangeable base cations $(\mathrm{Ca}, \mathrm{Mg}, \mathrm{K}$, and $\mathrm{Na}$ ) were assessed by the ammonium acetate $(1 \mathrm{M})$ adjusted to $\mathrm{pH}$ 7. The content of noncrystalline ferruginous and aluminous constituents was evaluated by differential solubility of $\mathrm{Fe}$ and $\mathrm{Al}$ forms by using the oxalic acid-ammonium oxalate buffer ( $\mathrm{pH} 3.2)$ (25). Base cations and extractable $\mathrm{Fe}$ and $\mathrm{Al}$ were determined by flame atomic absorption spectrometry (FAAS). Results were expressed on a dry basis $\left(105^{\circ} \mathrm{C}\right)$.

Mineral constitution of bentonites was assessed by XRD. Samples were grinded to a size $<50 \mu \mathrm{m}$, oriented on glass slides, and then scanned and air-dried after ethylene glycol solvation and after heating to $550{ }^{\circ} \mathrm{C}$. Scannings were performed in the angular range of $2-45^{\circ}$ $2 \theta$ using $\mathrm{Cu} \mathrm{K} \alpha$ radiation $(40 \mathrm{~V}, 20 \mathrm{~mA})$ and a $0.02^{\circ} 2 \theta \mathrm{s}^{-1}$ scanning speed, $2 \mathrm{~s}$ counting time. X-ray diffractograms were recorded with a Philips X-ray diffractometer (a PW 1732 generator, a PW 1050 goniometer, and a PV 1710 control unit using the PC-APD software version 3.6B).

External specific surface area was determined by the indirect method BET (Brunauer-Emmett-Teller 1938) using a Gemini II 2370 apparatus. A continuous stream of $\mathrm{N}_{2}$ and $\mathrm{He}$ was passed through a dry atmosphere previously cooled nearly to $\mathrm{N}_{2}$ boiling point. Then, a $\mathrm{N}_{2}$ single molecular layer was adsorbed on bentonite particles, and its volume was quantified ( $\mathrm{N}_{2}$ molecular surface is a known characteristic). Subsequently, the temperature of bentonite samples was increased to room temperature, causing $\mathrm{N}_{2}$ release, and its volume was measured. The external specific surface area was calculated applying the two $\mathrm{N}_{2}$ measured volumes and the BET equation. Because of their different particle size, bentonite samples were fragmented using a mortar before analysis.

For chemical analysis, bentonite samples were grinded to a size $<50$ $\mu \mathrm{m}$, dried at $105^{\circ} \mathrm{C}$, and separated in two parts. One part was used to determine the ignition loss $\left(1000{ }^{\circ} \mathrm{C}, 30 \mathrm{~min}\right)$, and the other for elemental composition analysis. Grinded bentonite samples were dissolved with a $\mathrm{HNO}_{3}(65 \% \mathrm{v} / \mathrm{v})$ and $\mathrm{HF}(50 \%$ v/v) solution using a microwave apparatus CEM-MDS 2000. The dissolved material was evaporated and once more dissolved with $\mathrm{HCl} 3 \mathrm{M}$ (25). Ca, Mg, Na, $\mathrm{K}, \mathrm{Mn}, \mathrm{Fe}$, and $\mathrm{Al}$ elements were determined by FAAS, and $\mathrm{P}$ by the molibdate colorimetric method (25). All these elements were expressed as oxides. The percentage of $\mathrm{Si}$ was estimated by the difference between 100 and the sum of all other elements. Other elements ( $\mathrm{Li}, \mathrm{Be}, \mathrm{B}, \mathrm{Sc}$, V, Mn, Co, Ni, Cu, Zn, Ga, Ge, As, Rb, Y, Zr, Nb, Mo, Cd, In, Sn, $\mathrm{Sb}, \mathrm{Cs}, \mathrm{Ba}, \mathrm{W}, \mathrm{Tl}, \mathrm{Pb}, \mathrm{Bi}$, and $\mathrm{U}$ ) were determined by inductively coupled plasma mass spectrometry (ICP-MS) semiquantitative approach (26) using a Perkin-Elmer SCIEX Elan 9000 apparatus equipped with a cross-flow nebulizer, a Ryton Scott-type spray chamber, nickel cones, and a peristaltic sample delivery pump with four channels (Gilson) (application software Elan-6100 Windows NT version 2.4). An autosampler Perkin-Elmer AS-93 Plus was protected by a laminar flow chamber clean room class 100 (Reinraumtechnik Max Petek). Operating conditions used were as follows: RF power of $1200 \mathrm{~W}$; sample uptake rate of $0.85 \mathrm{~mL} / \mathrm{min}$; nebulizer argon flow between 0.85 and $0.95 \mathrm{~L} / \mathrm{min}$. A full mass spectrum $(\mathrm{m} / \mathrm{z}=6-240$, omitting the mass ranges $16-18$; $40,41,211-229)$ was obtained by full mass range scanning. A reference response table (Perkin-Elmer TotalQuant III) was updated with a multielement standard solution ( $\mathrm{Li}, \mathrm{Be}, \mathrm{Na}, \mathrm{Mg}, \mathrm{Al}, \mathrm{K}, \mathrm{Ca}, \mathrm{V}, \mathrm{Cr}, \mathrm{Mn}$, $\mathrm{Fe}, \mathrm{Co}, \mathrm{Ni}, \mathrm{Cu}, \mathrm{Zn}, \mathrm{Ga}$, As, Se, Rb, Sr, Ag, Cd, In, Cs, Ba, Hg, Tl, Pb, $\mathrm{Bi}, \mathrm{U}$ ) at $10 \mu \mathrm{g} / \mathrm{L}$, from Perkin-Elmer. Rhodium (Rh) and rhenium $(\mathrm{Re})$ were used as internal standards for elements in the mass range $(\mathrm{m} / \mathrm{z})$ 7-138 and 205-238, respectively. The software of the instrument performed automatic corrections of isobaric interferences. In an early step, potential polyatomic interferences, their interference free ranges and interference ratios were evaluated. Preliminary tests in order to determine internal calibration recoveries showed similar values to those obtained by external calibration (26). To get signal stabilization, a sample read delay of $75 \mathrm{~s}$ was chosen. Between samples or standards, the sampling system was rinsed with a $2 \% \mathrm{HNO}_{3}(\mathrm{v} / \mathrm{v}), 1 \% \mathrm{C}_{2} \mathrm{H}_{5} \mathrm{OH}$ (v/v), and $200 \mu \mathrm{g} / \mathrm{L}$ of Au solution for $75 \mathrm{~s}$. The experimental conditions used for the measurements were: dwell time $=50 \mathrm{~ms}$; sweeps/reading $=6$; reading $/$ replicates $=1$; replicates $=1$; time per run $=67 \mathrm{~s}$. Only high purity reagents and deionized water (conductivity $<0.1 \mu \mathrm{S} / \mathrm{cm}$ ) were used. All the material (polypropylene and Teflon PFA) was soaked in $20 \% \mathrm{HNO}_{3}(\mathrm{v} / \mathrm{v})$ for at least $24 \mathrm{~h}$ and rinsed several times with 
Table 2. Physical and Chemical Characteristics of Bentonites: External Specific Surface, Particle Size Fractions, Organic Carbon Level, pH, and Exchange Complex Characteristics ${ }^{a}$

\begin{tabular}{|c|c|c|c|c|c|c|c|c|c|c|c|c|c|c|}
\hline \multirow[b]{2}{*}{ bentonite } & \multirow[b]{2}{*}{$\begin{array}{c}\text { specific } \\
\text { surface } \mathrm{m}^{2} / \mathrm{g}\end{array}$} & \multicolumn{4}{|c|}{ particle size fractions } & \multirow[b]{2}{*}{$\begin{array}{c}\text { C org, } \\
\text { g/kg }\end{array}$} & \multirow[b]{2}{*}{$\mathrm{pH} \mathrm{H}_{2} \mathrm{O}$} & \multicolumn{7}{|c|}{ exchange complex } \\
\hline & & $\begin{array}{l}\mathrm{CS}, \\
\mathrm{g} / \mathrm{kg}\end{array}$ & $\begin{array}{l}\text { FS, } \\
\mathrm{g} / \mathrm{kg}\end{array}$ & $\begin{array}{l}\mathrm{SL}, \\
\mathrm{g} / \mathrm{kg}\end{array}$ & $\begin{array}{l}\mathrm{CL}, \\
\mathrm{g} / \mathrm{kg}\end{array}$ & & & $\begin{array}{c}\mathrm{Ca}, \\
\mathrm{cmolc} / \mathrm{kg}\end{array}$ & $\begin{array}{c}\mathrm{Mg}, \\
\mathrm{cmolc} / \mathrm{kg}\end{array}$ & $\begin{array}{c}\mathrm{K}, \\
\mathrm{cmol} / \mathrm{kg}\end{array}$ & $\begin{array}{c}\mathrm{Na}, \\
\mathrm{cmolc} / \mathrm{kg}\end{array}$ & $\begin{array}{c}\mathrm{SB}, \\
\mathrm{cmolc} / \mathrm{kg}\end{array}$ & $\begin{array}{c}\text { CEC, } \\
\mathrm{cmolc} / \mathrm{kg}\end{array}$ & $\begin{array}{c}\text { SB/CEC, } \\
\%\end{array}$ \\
\hline B3 & 26.9 & 0.1 & 79.4 & 270.2 & 650.3 & 0.7 & 10.21 & 12.6 & 13.5 & 1.56 & 69.1 & 96.8 & 59.9 & 161.7 \\
\hline B4 & 20.4 & 0.1 & 65.7 & 307.4 & 626.8 & 1.4 & 10.31 & 16.8 & 9.9 & 1.68 & 74.4 & 102.8 & 57.0 & 180.3 \\
\hline B5 & 38.4 & 2.1 & 160.6 & 179.9 & 657.4 & 3.1 & 10.06 & 29.7 & 15.8 & 1.62 & 73.4 & 120.4 & 72.5 & 166.0 \\
\hline B8 & 31.2 & 0.2 & 63.7 & 308.7 & 627.4 & 2.3 & 10.22 & 25.8 & 14.7 & 1.77 & 90.4 & 132.6 & 58.4 & 226.2 \\
\hline
\end{tabular}

${ }^{a}$ CS: coarse sand; FS: fine sand; SL: silt; CL: clay; SB: sum of bases; CEC: cation exchange capacity; SB/CEC: cation exchange proportion on exchange complex.

deionized water before use. For validation of the results, the contents of some elements $(\mathrm{Cu}, \mathrm{Cd}$, and $\mathrm{Pb})$ were also determined by electrothermal atomic absorption spectrometry (ETAAS) and those of Zn by FAAS.

Extraction Essays. Extraction essays were based in a factorial experiment with two factors: bentonite (control, B1, B3, B4, B5, B8, and B9) and wine $\mathrm{pH}$ value $(2.94,3.32$, and 3.58). To simulate the natural $\mathrm{pH}$ range occurring in Portuguese wines, three lots with different $\mathrm{pH}$ levels $(2.94,3.32$, and 3.58$)$ were obtained by adding tartaric acid $(3.20 \mathrm{~g} / \mathrm{L}$ and $0.55 \mathrm{~g} / \mathrm{L})$ and calcium carbonate $(0.80 \mathrm{~g} / \mathrm{L})$ to a white wine from 2001 vintage. Each extraction was replicated three times.

The dose of bentonite used in this study $(25 \mathrm{~g} / \mathrm{L})$ was higher than that usually used in winemaking but lower than the concentration established by the OIV (5) for bentonite quality control (100 g/L). This was to amplify the mineral release extent and consequently to detect eventual effects of bentonites.

A sample of $5 \mathrm{~g}$ bentonite $\left(105^{\circ} \mathrm{C}\right.$ drying) was shaken with $200 \mathrm{~mL}$ of wine in an Erlenmeyer vessel for 15 min After $24 \mathrm{~h}$ of decantation, the suspension was centrifuged at $12000 \mathrm{rpm}$ during $30 \mathrm{~min}$, and the supernatant was used for measurements. Control samples (wine without bentonite addition) were simultaneous and similarly prepared at the same $\mathrm{pH}$, stirred, and centrifuged. Before use, the polypropylene material was soaked in $20 \% \mathrm{HNO}_{3}(\mathrm{v} / \mathrm{v})$ for at least $24 \mathrm{~h}$ and rinsed several times with purified water. Measurements of $\mathrm{Na}, \mathrm{Mg}, \mathrm{K}, \mathrm{Ca}$, and $\mathrm{Fe}$ were made by FAAS (27) and Al by ETAAS (28), while Li, Be, B, Sc, V, Mn, Fe, Co, $\mathrm{Ni}, \mathrm{Cu}, \mathrm{Zn}, \mathrm{Ga}, \mathrm{Ge}, \mathrm{As}, \mathrm{Rb}, \mathrm{Sr}, \mathrm{Y}, \mathrm{Zr}, \mathrm{Nb}, \mathrm{Mo}, \mathrm{Cd}$, In, Sn, Sb, Ba, W, Tl, $\mathrm{Pb}, \mathrm{Bi}$ and $\mathrm{U}$ were analyzed by the ICP-MS semiquantitative approach as described before (26).

Statistical Analysis. The variance analysis was performed using Statistica 5.1 data analysis software (Statsoft Inc., 1998).

Regardomg the $\mathrm{pH}$ effect, for each $\mathrm{pH}$ value, the average of the corresponding seven modalities (control wine and bentonite treated wines: B1, B3, B4, B5, B8, and B9), considering the three independent replicates, was calculated. Concerning the bentonite effect, for each modality of extraction (control, B1, B3, B4, B5, B8, and B9), the average value obtained from the three levels of $\mathrm{pH}$, considering the three independent replicates, was calculated.

\section{RESULTS AND DISCUSSION}

Physical and Chemical Characteristics of Bentonites. External specific surface area, particle size fractions, organic carbon content, $\mathrm{pH}$ values, and exchange complex characteristics of studied bentonites are shown in the Table 2. Concerning particle size fractions, studied bentonites showed negligible content of coarse sand; the B5 and specially the B1 samples showed high contents of fine sand, while the B9 contained low contents of fine sand and silt and the highest content of clay, suggesting a high reactivity. Admitting that the clay fraction was exclusively constituted by montmorillonite, only the B9 may have a content close to that established by the OIV (80\%) (5).

A precise evaluation of all mineral constituents of bentonite is required to assess their characteristics and behavior. Diffractograms of bentonites after ethylene glycol solvation are shown

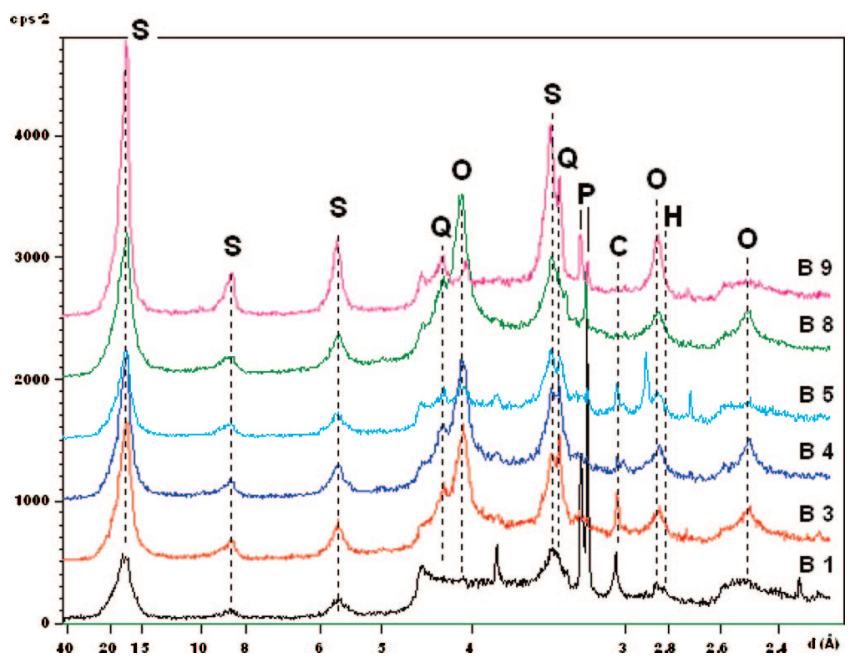

Figure 1. X-ray diagram of bentonites (after ethylene glycol solvation). S: smectite; O: opal; Q: quartz; P: plagioclase; C: calcite; H: halite.

in Figure 1. As expected, minerals of the smectite group were predominant in all bentonite samples, especially montmorillonite, and probably also beidelite in the B1 and B5 samples. In addition, other minerals in variable proportions were present, such as quartz and probably opal in the samples B3, B4, B5, and B8, calcite in the B1, B3, and especially B5, plagioclase in the $\mathrm{B} 1$ and $\mathrm{B} 3$, and halite in the B5. The B1 differed from the other samples due to its high proportion of inert constituents (approximately 20\%). On the contrary, the B9 showed a smectite high proportion, with inert constituents being less than $5 \%$. Moreover, the bentonites may also contain amorphous materials (not detected by the applied method), susceptible to release $\mathrm{Ca}$, $\mathrm{Mg}$, or $\mathrm{Na}$, and also minor and trace elements.

The values of external specific surface area ranged from 13.4 to $38.3 \mathrm{~m}^{2} / \mathrm{g}$, respectively, in the B9 and B5 samples. Differences between samples are not relevant and therefore cannot explain distinct mineral release capacity by itself. The B9 sample showed the highest montmorillonite content and the lowest value of external specific surface area, suggesting that clay fraction characteristics are more important than its content. Information on the internal specific surface area would be necessary to get deeper understanding on bentonite reactivity.

It is understood that each clay mineral presents a characteristic range of cation exchange capacity values. Because bentonites are complex combinations of various minerals, the results are difficult to interpret. For example, the B1 showed the highest cation exchange capacity $\left(80.4 \mathrm{cmol}_{\mathrm{C}} / \mathrm{kg}\right)$, followed by the B5 and B9 $\left(72.5 \mathrm{cmol}_{\mathrm{C}} / \mathrm{kg}\right)$, whereas the B3, B4, and B8 samples presented considerably lower cation exchange capacity (57.0-59.9 $\mathrm{cmol}_{\mathrm{c}} / \mathrm{kg}$ ). Bearing in mind the particle size fractions of bentonites, these results are interesting. The bentonite with the 
Table 3. $\mathrm{Ca}, \mathrm{Mg}, \mathrm{Na}, \mathrm{K}, \mathrm{Mn}, \mathrm{Fe}, \mathrm{Al}$, and P Contents in Bentonites, Expressed as Oxides; Si was Obtained by the Difference between $100 \%$ and the Sum of the other Elements Percentage, Ignition Loss, and Noncrystalline Fe and Al

\begin{tabular}{|c|c|c|c|c|c|c|c|c|c|c|c|c|}
\hline bentonite & $\mathrm{CaO}, \%$ & $\mathrm{MgO}, \%$ & $\mathrm{Na}_{2} \mathrm{O}, \%$ & $\mathrm{~K}_{2} \mathrm{O}, \%$ & $\mathrm{MnO}, \%$ & $\mathrm{Fe}_{2} \mathrm{O}_{3}, \%$ & $\mathrm{Al}_{2} \mathrm{O}_{3}, \%$ & $\mathrm{P}_{2} \mathrm{O}_{5}, \%$ & ignition loss, $\%$ & $\mathrm{SiO}_{2}, \%$ & \multicolumn{2}{|c|}{ noncrystalline $\mathrm{Fe}$ and $\mathrm{Al}$} \\
\hline B1 & 17.31 & 0.71 & 3.79 & 0.27 & 0.05 & 2.85 & 32.32 & 0.04 & 10.57 & 32.09 & 0.19 & 0.89 \\
\hline B4 & 5.95 & 13.08 & 10.95 & 0.71 & 0.03 & 1.56 & 17.60 & 0.03 & 10.84 & 39.28 & 0.25 & 0.58 \\
\hline B5 & 16.29 & 1.49 & 3.88 & 1.02 & 0.12 & 3.85 & 28.89 & 0.11 & 8.67 & 35.68 & 1.39 & 0.93 \\
\hline B8 & 2.96 & 1.34 & 3.19 & 0.16 & 0.02 & 1.46 & 13.52 & 0.46 & 6.41 & 70.48 & 0.36 & 1.11 \\
\hline B9 & 3.06 & 0.72 & 2.80 & 0.34 & 0.02 & 3.35 & 16.89 & 0.05 & 6.91 & 65.86 & 0.58 & 0.86 \\
\hline
\end{tabular}

lowest clay content (B1) showed the highest cation exchange capacity (CEC), while the B9 with the highest clay content (79\%), suggesting a high reactivity, exhibited a low CEC value. These results are probably related to montmorillonite structural particularities and suggest that its content is not a satisfactory indicator of bentonite reactivity. Thus, montmorillonite content is not sufficient for bentonite characterization.

Concerning exchangeable bases (Table 2), Ca content in the exchange complex seemed to be related to the bentonite nature. In fact, activated bentonites showed the highest concentrations, mainly in the B1. On the other hand, the highest content of $\mathrm{Na}$ was observed in the B8, a natural $\mathrm{Na}$ bentonite.

As expected, low values of organic carbon were observed (Table 2). Nevertheless, the B5 sample showed the highest content $(3.1 \mathrm{~g} / \mathrm{kg})$, which was nearly four times the content determined for the B3 sample. As is well-known, organic material contains mineral elements by complexation phenomena, which are susceptible to react in solution.

Bentonite elemental composition ( $\mathrm{Ca}, \mathrm{Mg}, \mathrm{Na}, \mathrm{K}, \mathrm{Mn}, \mathrm{Fe}$, $\mathrm{Al}$, and $\mathrm{P}$ elements), expressed as oxides, is shown in Table $\mathbf{3}$. High $\mathrm{CaO}$ contents in the $\mathrm{B} 1$ and $\mathrm{B} 5$ samples $(17.3 \%$ and $16.3 \%$, respectively) are in agreement with the presence of calcite (Figure 1), and the high $\mathrm{Na}_{2} \mathrm{O}$ content in the $\mathrm{B} 1$ can be related to the presence of plagioclase (albite). Considering the mineralogical composition of bentonites, there is no explanation either for the high content of $\mathrm{MgO}$ in the $\mathrm{B} 3$ and $\mathrm{B} 4$ samples ( $17.0 \%$ and $13.1 \%$, respectively) or for the level of $\mathrm{Na}_{2} \mathrm{O}$ in the B4 (11\%). A possible explanation for these contents is that the B3 and B4 samples probably contain trioctahedral smectites (magnesian smectites).

The OIV defines limit values for a set of elements to be determined in a bentonite extraction solution that is a tartaric acid solution (5). However, the unsuitability of the test solution recommended by the OIV for bentonite quality purposes, concerning its potential effect on wine elemental composition, was recently demonstrated (29). The interpretation of the results concerning $\mathrm{Fe}$ and $\mathrm{Al}$ extractable contents should take into account that they were obtained by using the oxalic acid-ammonium oxalate buffer. Therefore, the comparison with the limits in use by the OIV is indicative.

In relation to extractable $\mathrm{Fe}$ contents (Table 3), strong differences were observed between the B1 and the B5 samples, showing the minimum and maximum values, respectively. It should be emphasized that the content of extractable Fe of the B5 largely exceeded the threshold of $600 \mathrm{mg} / \mathrm{kg}$ established by the OIV (5). Extractable Al contents ranged from $0.58 \mathrm{~g} / \mathrm{kg}$ (B4) to $1.11 \mathrm{~g} / \mathrm{kg}$ (B8), being lower than the limit of $2.5 \mathrm{~g} / \mathrm{kg}$ established by the OIV (5). Contrarily to extractable Al, extractable Fe was correlated with the total $\mathrm{Fe}$ in the bentonite sample $(r=0.740, P=0.05)$.

The results regarding some minor and trace elements are reported in Figure 2. For the most of the studied elements, including $\mathrm{Al}$ and $\mathrm{Fe}$, the highest contents were observed in the B1, B5, and B9 samples.

In conclusion, some bentonite characteristics were in disagreement with OIV specifications: none of the bentonites contained the required minimum content of montmorillonite; the B5 bentonite exceeded the allowed maximum content of extractable Fe. On the other hand, assuming that clay fraction properties were more important than its content, the montmorillonite content did not seem to be a satisfactory indicator of bentonite reactivity.

Elemental Composition of Bentonite Treated Wines. The composition of control and bentonite treated wines are shown in Table 4. It should be stressed that, for each modality (control, B1, B3, B4, B5, B8 and B9), the results are based on average values obtained from the three levels of $\mathrm{pH}$. The interpretation of the results should take into account that they were obtained under experimental conditions, with a bentonite dose higher than that commonly used in winemaking. Therefore, concerning the content increases or decreases, these results are indicative and show a series of tendencies for different elements.

Wines treated with bentonites showed significantly different concentrations of all the elements studied $(P=0.05)$ compared to the control (Table 4).

Enrichment of Elements of Technological and/or Legal Interest. Bentonite treatment resulted in significantly higher concentration of a large group of elements ( $\mathrm{Li}, \mathrm{Be}, \mathrm{Na}, \mathrm{Mg}$, $\mathrm{Al}, \mathrm{Ca}, \mathrm{Sc}, \mathrm{V}, \mathrm{Mn}, \mathrm{Fe}, \mathrm{Co}, \mathrm{Ni}, \mathrm{Ga}, \mathrm{Ge}, \mathrm{As}, \mathrm{Sr}, \mathrm{Y}, \mathrm{Zr}, \mathrm{Nb}, \mathrm{Mo}$, $\mathrm{Cd}, \mathrm{Sn}, \mathrm{Sb}, \mathrm{Ba}, \mathrm{W}, \mathrm{Tl}, \mathrm{Bi}$, and $\mathrm{U}$ ), some of them contaminants legally controlled.

Calcium concentration in wines increased from $54 \%$ to $237 \%$, which is very interesting as $\mathrm{Ca}$ concentration affects the tartaric stability of wine. The increments of $\mathrm{Na}$ concentrations in wines (from $339 \%$ to $482 \%$ ) are important because $\mathrm{Na}$ enrichment in wine could carry legal implications (30). It should be noted that none of the natural bentonites (B3, B8, and B9) respected the maximum soluble sodium content defined by OIV of $10 \mathrm{~g} / \mathrm{kg}$ (5). As previously pointed out, the comparison of the results with the limits in use by the OIV is indicative.

As regards to some minor elements in wine with relevant technological interest, remarkable $\mathrm{Al}$ enrichments up to 16 times were observed. Fe enrichments varied between $25 \%$ and $350 \%$. Bearing in mind the potential Fe precipitation phenomena, these increments are relevant. Extractable $\mathrm{Al}$ and $\mathrm{Fe}$ contents from bentonites were in accordance with the limits defined by the OIV $(2.5 \mathrm{~g} / \mathrm{kg}$ and $600 \mathrm{mg} / \mathrm{kg}$, respectively).

Concerning elements under legal control, particular attention must be paid to remarkable As enrichments, from 163 to $3621 \%$, particularity from the B9. Bearing in mind the OIV maximum contents for extractable As $(2 \mathrm{mg} / \mathrm{kg})$, the B9 should be signalized as being responsible for a As release of $1.87 \mathrm{mg} / \mathrm{kg}$. The maximum acceptable value for As in wine is $0.2 \mathrm{mg} / \mathrm{L} \mathrm{(30).}$ $\mathrm{Cd}$ introductions were technologically irrelevant, as final 

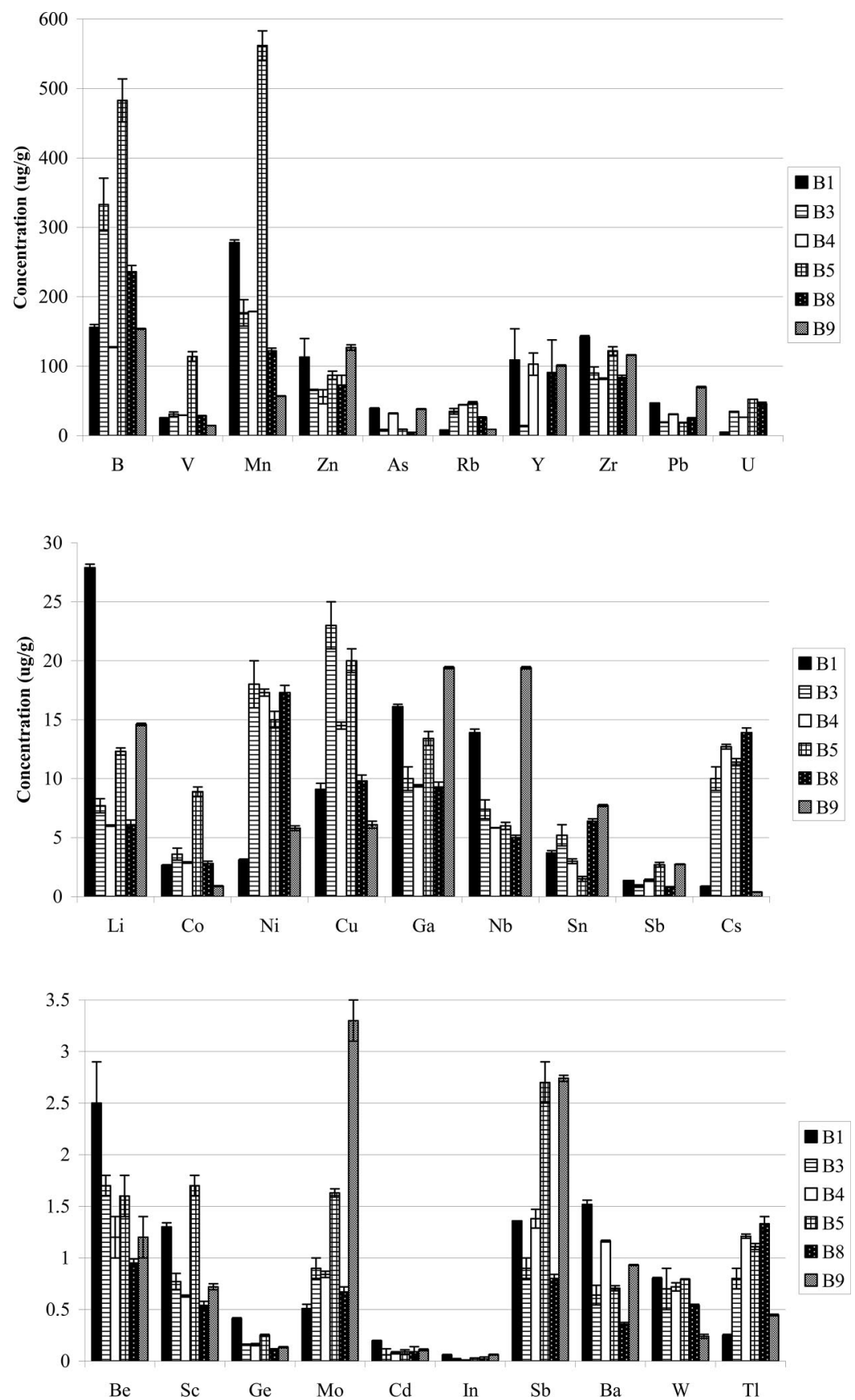

Figure 2. Multielemental composition of bentonites $(n=3$, the results are expressed in $\mu \mathrm{g} / \mathrm{g}$, except for $\mathrm{Ba}$, $\mathrm{mg} / \mathrm{g}$ ).

concentrations were very distant from the legal limit $(0.01 \mathrm{mg} /$ L). All bentonites were in conformity with OIV maximum contents for extractable $\mathrm{Pb}(5 \mathrm{mg} / \mathrm{kg})$. Distinct bentonite effects were observed on $\mathrm{Pb}$ wine contents: enrichments were promoted by the B1 and mainly by B9. The maximum acceptable value for $\mathrm{Pb}$ in wine is of $0.15 \mathrm{mg} / \mathrm{L}(30)$. In contrast, the $\mathrm{B} 4, \mathrm{~B} 5$, and $\mathrm{B} 8$ leaded to $\mathrm{Pb}$ depletion. The most reasonable explanation for distinct trends is that $\mathrm{Pb}$ release from $\mathrm{B} 4, \mathrm{~B} 5$, and $\mathrm{B} 8$ bentonites to wine was lower than its depletion due to the formation of proteins and polysaccharides complexes. On a distinct application field but somehow related with these observations, bentonite ability to remove certain heavy metals from liquid waste have been observed (31).

Decrease of Element of Technological and/or Legal Interest. Concentrations of $\mathrm{B}, \mathrm{K}, \mathrm{Cu}, \mathrm{Zn}$, and $\mathrm{Rb}$ in wine significantly decreased after bentonite treatment (Table 4). Variations of $\mathrm{K}$ $(-20 \%$ to $-35 \%), \mathrm{Zn}(-20 \%$ to $-37 \%)$, and mainly $\mathrm{Cu}(-70 \%$ to $-93 \%$ ) were very interesting, as they contribute to wine tartaric stabilization and to limit $\mathrm{Cu}$ wine haze. It should be mentioned that $\mathrm{Cu}$ and $\mathrm{Zn}$ concentrations in wine are legally controlled, with maximum acceptable values of 1 and $5 \mathrm{mg} / \mathrm{L}$, respectively (30).

Probably, $\mathrm{K}$ is removed from wine through an exchange with $\mathrm{Na}$ and $\mathrm{Ca}$ in exchange positions (among other cations). This hypothesis is supported both by its natural high concentration in wine and by its high affinity to aluminum silicates structure. Similar explanation is credible for $\mathrm{Rb}$ decrease, likewise, $\mathrm{K}$, an element of low ionic potential. Proteins and $\mathrm{K}$ competition to bentonite adsorption have been previously reported (10).

Depletion of $\mathrm{B}, \mathrm{Cu}$, and $\mathrm{Zn}$ may be related to their complexation with condensed tannins, which are in part bound to proteins. Additionally, $\mathrm{Zn}$ could be complexed with dimmers of rhamnogalacturonan II, a grape pectic polysaccharide (32). 
Table 4. Effect of the Bentonite and $\mathrm{pH}$ Value on the Multielemental Compositon of Wine (Results are Given in $\mu \mathrm{g} / \mathrm{L}$, except for $\mathrm{Na}$, Mg, $\mathrm{Al}, \mathrm{K}, \mathrm{Ca}$, and Fe, Which are Expressed as $\mathrm{mg} / \mathrm{L}^{\mathrm{a}}$

\begin{tabular}{|c|c|c|c|c|c|c|c|c|c|c|c|c|c|}
\hline \multirow[b]{2}{*}{ element } & \multirow{2}{*}{$\begin{array}{c}\mathrm{pH} \\
\text { effect }^{b}\end{array}$} & \multicolumn{3}{|c|}{$\mathrm{pH}$ level $(n=7)$} & \multirow{2}{*}{$\begin{array}{l}\text { bentonite } \\
\text { effect }^{b}\end{array}$} & \multicolumn{7}{|c|}{ bentonite $(n=3)$} & \multirow{2}{*}{$\begin{array}{l}\text { pH-bentonite } \\
\text { interaction }^{b}\end{array}$} \\
\hline & & 2.94 & 3.32 & 3.58 & & control & B1 & B3 & B4 & B5 & B8 & B9 & \\
\hline $\mathrm{Li}$ & ** & 20.31 b & $16.50 \mathrm{a}$ & $16.53 \mathrm{a}$ & ** & 10.71 a & $19.53 \mathrm{~b}$ & $11.39 a$ & $10.99 a$ & $11.02 \mathrm{a}$ & $10.90 \mathrm{a}$ & $49.90 \mathrm{c}$ & ** \\
\hline $\mathrm{Be}$ & ** & $11.31 \mathrm{c}$ & $8.17 \mathrm{~b}$ & $5.53 \mathrm{a}$ & ** & $0.09 a$ & $15.18 \mathrm{f}$ & $9.12 \mathrm{~d}$ & $6.78 \mathrm{~b}$ & $8.92 \mathrm{~d}$ & $7.98 \mathrm{c}$ & $10.28 \mathrm{e}$ & ** \\
\hline $\mathrm{Na}$ & n.s. & 421.9 & 419.9 & 428.2 & ** & $90.2 \mathbf{a}$ & 419.8 c & $490.8 \mathrm{~d}$ & $517.1 \mathrm{e}$ & $525.1 \mathrm{e}$ & 524.5 e & $395.8 \mathrm{~b}$ & n.s. \\
\hline $\mathrm{Mg}$ & n.s. & 112.19 & 112.48 & 113.05 & ** & $69.11 \mathrm{a}$ & 98.89 b & $156.22 \mathrm{f}$ & $152 \mathrm{e}$ & $131.78 \mathrm{~d}$ & $109.33 \mathrm{c}$ & 70.67 a & *夫 \\
\hline $\mathrm{Al}$ & ** & $14.383 \mathrm{c}$ & $13.163 b$ & $12.229 a$ & ** & $1.223 \mathbf{a}$ & $15.107 \mathrm{c}$ & $14.394 \mathrm{c}$ & $12.017 \mathbf{b}$ & 12.725 b & 20.988 e & $16.355 \mathrm{~d}$ & 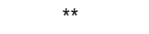 \\
\hline V & ** & $28.89 \mathrm{c}$ & $22.04 b$ & $16.61 \mathrm{a}$ & ** & $5.32 \mathrm{a}$ & $32.70 \mathrm{~d}$ & $25.14 \mathrm{C}$ & $24.85 \mathrm{c}$ & $45.91 \mathrm{e}$ & $17.63 \mathbf{b}$ & $5.76 \mathrm{a}$ & ** \\
\hline $\mathrm{Mn}$ & ** & $1675.61 \mathrm{c}$ & $1429.67 \mathrm{~b}$ & $1101.64 \mathbf{a}$ & ** & $460.34 \mathbf{a}$ & $1519.10 \mathrm{c}$ & $1814.92 \mathrm{~d}$ & $1947.65 \mathrm{e}$ & $2868.29 \mathrm{f}$ & 750.29 b & $455.56 \mathbf{a}$ & ** \\
\hline $\mathrm{Fe}$ & ** & $5.11 \mathbf{b}$ & $6.02 \mathrm{c}$ & $3.93 a$ & ** & $1.84 \mathrm{a}$ & $2.30 \mathrm{~b}$ & $4.56 \mathrm{c}$ & $4.95 \mathrm{~d}$ & $8.27 \mathbf{b}$ & $6.12 \mathrm{e}$ & $7.10 \mathrm{f}$ & *夫 \\
\hline Co & ** & $19.04 \mathrm{c}$ & $15.80 \mathrm{~b}$ & $13.00 \mathrm{a}$ & ** & $1.92 \mathbf{a}$ & $6.79 \mathrm{~b}$ & $26.43 \mathrm{e}$ & $24.31 \mathrm{~d}$ & $25.88 \mathrm{e}$ & $20.48 \mathrm{c}$ & $5.81 \mathrm{~b}$ & 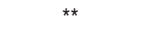 \\
\hline $\mathrm{Ni}$ & ** & $64.28 \mathrm{c}$ & $55.55 \mathrm{~b}$ & $48.05 a$ & ** & $23.18 \mathrm{a}$ & $25.89 a$ & $94.91 \mathrm{e}$ & $99.95 f$ & $49.28 \mathrm{c}$ & $66.00 \mathrm{~d}$ & $32.52 \mathrm{~b}$ & ** \\
\hline $\mathrm{Cu}$ & *夫 & $23.45 c$ & $18.79 b$ & $11.48 \mathrm{a}$ & ** & $57.23 e$ & $13.45 c$ & $11.64 b, c$ & $12.35 \mathrm{c}$ & $9.22 \mathbf{b}$ & $17.44 \mathrm{~d}$ & $4.01 \mathrm{a}$ & *夫 \\
\hline $\mathrm{Zn}$ & ** & $580.19 \mathrm{c}$ & $477.67 \mathrm{~b}$ & $377.64 \mathbf{a}$ & ** & $623.22 \mathrm{e}$ & $390.11 \mathbf{a}$ & $489.27 \mathrm{~d}$ & $487.37 \mathrm{c}, \mathrm{d}$ & 413.25 a,b & 446.40 b,c & $499.86 \mathrm{~d}$ & ** \\
\hline $\mathrm{Sr}$ & ** & $700.79 b$ & 568.29 a & 714.24 b & ** & $158.55 \mathrm{a}$ & $885.85 \mathrm{~d}$ & 560.64 b,c & $543.20 \mathrm{~b}$ & $605.13 \mathrm{c}$ & $505.13 \mathrm{~b}$ & $1369.24 \mathrm{~d}$ & ** \\
\hline Y & *夫 & $4.58 \mathrm{~b}$ & $1.25 \mathrm{a}$ & $5.64 \mathbf{b}$ & ** & $0.04 a$ & $3.95 \mathrm{c}, \mathrm{d}$ & $4.67 \mathrm{~d}$ & $3.71 \mathrm{c}$ & $2.10 \mathrm{~b}$ & $3.88 \mathrm{c}, \mathrm{d}$ & $8.39 \mathrm{e}$ & ** \\
\hline $\mathrm{Zr}$ & ** & $231.76 \mathrm{c}$ & 160.98 b & $98.22 \mathbf{a}$ & ** & $1.47 \mathrm{a}$ & $392.25 \mathrm{~g}$ & $119.55 \mathrm{c}$ & $76.55 \mathrm{~b}$ & $138.69 \mathrm{~d}$ & $150.51 \mathrm{e}$ & $266.54 \mathrm{f}$ & ** \\
\hline $\mathrm{Nb}$ & ** & $9.89 \mathrm{c}$ & $6.75 \mathrm{~b}$ & $4.80 \mathrm{a}$ & ** & $0.03 a$ & $16.86 \mathbf{b}$ & $0.56 \mathrm{a}$ & $0.29 a$ & $0.11 \mathrm{a}$ & $0.13 a$ & $30.01 \mathrm{c}$ & ** \\
\hline Mo & ** & $8.01 \mathrm{~b}$ & $5.08 a$ & $4.96 \mathbf{a}$ & ** & $1.33 \mathrm{a}$ & $2.09 \mathrm{~b}$ & $3.29 c, d$ & $3.25 \mathrm{c}, \mathrm{d}$ & $3.76 \mathrm{~d}$ & $2.76 \mathrm{c}$ & 25.63 e & ** \\
\hline $\mathrm{Cd}$ & ** & $0.691 \mathrm{~b}$ & $0.584 \mathrm{a}$ & $0.712 b$ & ** & $0.218 a$ & $0.998 \mathrm{e}$ & $0.563 c$ & $0.750 \mathrm{~d}$ & $0.455 \mathrm{~b}$ & 0.985 e & $0.667 \mathrm{~d}$ & 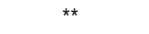 \\
\hline In & n.s. & $0.07 a$ & $0.04 a$ & $0.06 a$ & ** & $0.01 \mathrm{a}$ & $0.02 \mathrm{a}$ & $0.01 \mathrm{a}$ & $0.01 \mathrm{a}$ & $0.01 \mathrm{a}$ & $0.01 \mathrm{a}$ & $0.33 \mathrm{~b}$ & n.s. \\
\hline Sn & ** & $3.42 \mathrm{c}$ & $1.69 \mathrm{~b}$ & $0.90 \mathrm{a}$ & ** & $0.70 \mathrm{~b}$ & $0.71 \mathrm{~b}$ & $0.88 \mathrm{c}, \mathrm{d}$ & $0.75 b, c$ & $0.54 a$ & $0.94 \mathrm{~d}$ & $9.50 \mathrm{e}$ & ** \\
\hline $\mathrm{Sb}$ & ** & $4.47 \mathrm{c}$ & $3.07 \mathrm{~b}$ & $2.65 \mathrm{a}$ & ** & $1.69 \mathrm{a}$ & $2.74 \mathrm{~b}$ & $1.87 \mathrm{a}$ & $1.86 \mathrm{a}$ & $3.67 \mathrm{c}$ & $1.81 \mathrm{a}$ & $10.13 d$ & ** \\
\hline $\mathrm{Ba}$ & ** & $102.59 \mathrm{a}$ & 109.24 b & $122.93 \mathrm{c}$ & ** & $39.31 \mathrm{a}$ & $76.90 \mathrm{c}$ & $184.45 \mathrm{e}$ & $278.50 \mathrm{f}$ & $60.34 b$ & $97.79 \mathrm{~d}$ & $43.83 \mathrm{a}$ & ** \\
\hline W & ** & $0.91 \mathbf{b}$ & $0.89 \mathrm{~b}$ & $0.70 \mathrm{a}$ & ** & $0.25 a$ & $1.55 \mathrm{f}$ & $1.33 \mathrm{e}$ & $1.61 \mathrm{~g}$ & $0.46 \mathrm{~d}$ & $0.35 \mathrm{c}$ & $0.31 \mathrm{~b}$ & ** \\
\hline $\mathrm{Tl}$ & ** & $2.21 \mathrm{a}$ & $2.33 \mathrm{~b}$ & $2.25 a$ & ** & $0.12 \mathrm{a}$ & $0.59 \mathrm{~b}$ & $2.86 \mathrm{e}$ & $3.11 \mathrm{f}$ & $2.12 \mathrm{~d}$ & $5.59 \mathrm{~g}$ & $1.42 \mathrm{c}$ & ** \\
\hline $\mathrm{Pb}$ & ** & $33.55 \mathrm{c}$ & 25.24 b & $15.79 a$ & ** & $21.49 c$ & $26.25 d$ & $20.27 \mathrm{c}$ & 17.35 b & $8.01 \mathrm{a}$ & $16.55 \mathrm{~b}$ & 64.08 e & ** \\
\hline $\mathrm{Bi}$ & *夫 & $1.44 \mathrm{~b}$ & $1.41 \mathrm{~b}$ & $1.14 \mathrm{a}$ & ** & $1.02 a, b$ & $2.08 \mathrm{e}$ & $1.51 \mathrm{~d}$ & $1.33 \mathrm{c}, \mathrm{d}$ & $1.45 \mathrm{~d}$ & $0.79 a$ & $1.27 \mathbf{b}, \mathbf{c}$ & ** \\
\hline$U$ & ** & $43.96 \mathbf{a}$ & $52.06 \mathrm{~b}$ & $57.35 \mathrm{c}$ & ** & $0.58 \mathrm{a}$ & $8.09 \mathrm{~b}$ & $22.62 \mathrm{c}$ & $35.73 d$ & $108.10 \mathrm{f}$ & $71.33 \mathrm{e}$ & $111.41 \mathrm{f}$ & ** \\
\hline
\end{tabular}

${ }^{a}$ Regarding the $\mathrm{pH}$ effect, for each $\mathrm{pH}$ value, the results are based on average values of the corresponding seven modalities (control wine and bentonite treated wines: $\mathrm{B} 1, \mathrm{~B} 3, \mathrm{~B} 4, \mathrm{~B} 5, \mathrm{~B} 8$, and B9). Concerning the bentonite effect, for each modality of extraction, the results are based on average values of the three levels of pH. ${ }^{b} \mathrm{Means}$ followed by the same letter in a line are not significantly different at the $0.05^{\star}$ or $0.01^{\star \star}$ level of significance; n.s. $=$ without significant difference.

Bentonites capacity to indirectly prevent wine $\mathrm{Cu}$ haze was already reported (33).

In conclusion, this study proves that bentonite affects the mineral composition of wines. Bentonite application resulted in significantly higher concentrations of a large group of elements. In contrast, the concentrations of $\mathrm{B}, \mathrm{K}, \mathrm{Cu}, \mathrm{Zn}$, and $\mathrm{Rb}$ in wine have significantly decreased. Distinct effects were observed for $\mathrm{Pb}$ wine contents, suggesting the bentonite ability remove it, which is remarkable from a technological point of view.

Once more, it is worth noting that some bentonite characteristics were in disagreement with OIV specifications. All studied bentonites exceeded the allowed maximum content of soluble Na. The B9 was responsible for an As release very near from the defined maximum content of extractable As.

Physical and Chemical Characteristics of Bentonites and Elemental Release. Concerning the studied elements, significant differences among bentonites were found, reinforcing the importance of bentonite chemical and structural characteristics on extraction phenomena (Table 4). The B1 sample showed a high release of $\mathrm{Li}, \mathrm{Be}, \mathrm{Ca}, \mathrm{Sc}, \mathrm{V}, \mathrm{Zr}, \mathrm{Nb}, \mathrm{Cd}$, and $\mathrm{Bi}$ and a depletion of $\mathrm{K}, \mathrm{Zn}$, and $\mathrm{Rb}$. These results are explained by its relatively high cation exchange capacity, calcite presence, and by its high proportion of inert constituents. The B3 and B4 should be noticed by the high introduction of $\mathrm{Mg}$ in wine, related to the probable presence of magnesian smectites. $\mathrm{Ni}$ and $\mathrm{Ba}$ releases were also relevant for those bentonites. The B3 and $\mathrm{B} 4$ were responsible for a low removal of $\mathrm{K}, \mathrm{Zn}$, and $\mathrm{Rb}$, which is in agreement with their low cation exchange capacity. The high $\mathrm{Ca}$ release from the $\mathrm{B} 5$ is ascribed to the presence of calcite. The remarkable introduction of V, Mn, Fe, Co, As, and $\mathrm{U}$ is probably due to the presence of noncrystalline materials. Moreover, $\mathrm{K}$ concentration in wine showed a strong decrease, reflecting an important cation exchange capacity. A remarkable addition of $\mathrm{Al}$ was observed for the $\mathrm{B} 8$. Ga and $\mathrm{Tl}$ introductions were also highest in this bentonite. Finally, the B9 was characterized by $\mathrm{Be}, \mathrm{Fe}, \mathrm{Y}$, and $\mathrm{Zr}$ release and in particular $\mathrm{Li}$, As, $\mathrm{Sr}, \mathrm{Nb}, \mathrm{Mo}, \mathrm{Sn}, \mathrm{Sb}, \mathrm{Pb}$, and $\mathrm{U}$ introductions. This bentonite showed a high organic $\mathrm{C}$ content, a smecticte high proportion, an important $\mathrm{CEC}$ and the lowest $\mathrm{Ca}, \mathrm{Mg}, \mathrm{K}$, and $\mathrm{Na}$ proportion in the exchange complex. Relevant amounts of $\mathrm{B}, \mathrm{Cu}$, and $\mathrm{Rb}$ were removed.

The correlation between the concentration of each element in treated wine and its content in bentonites was assessed $(P=$ $0.05)$. Na concentrations in wines were positively correlated with its proportion in bentonite exchange complex $(r=0.881)$ but not with its total content in bentonites. In fact, part of the $\mathrm{Na}$ is included in plagioclase mineral, thus being unattainable. Increments of $\mathrm{Al}$ and $\mathrm{Fe}$ in wines were positively correlated with extractable $\mathrm{Al}(r=0.784)$ and $\mathrm{Fe}(r=0.808)$ constituents in bentonites. Regarding bentonite multielemental composition, correlation values higher than 0.800 were found for: $\mathrm{Li}(r=$ 0.826 , if B1 is excluded); $\mathrm{Be}(r=0.857), \mathrm{Mg}(r=0.820), \mathrm{Ca}$ $(r=0.981), \mathrm{V}(r=0.812), \mathrm{Mn}(r=0.814), \mathrm{Ni}(r=0.867)$, $\mathrm{Ge}(r=0.988$, if $\mathrm{B} 9$ is excluded $), \mathrm{Zr}(r=0.836), \mathrm{Nb}(r=$ 0.992), Mo ( $r=0.948), \mathrm{Sn}(r=0.967$, if B9 is excluded $), \mathrm{Sb}$ 
( $r=0.920$, if $\mathrm{B} 9$ is excluded $), \mathrm{Tl}(r=0.839), \mathrm{Pb}(r=0.933)$, and $\mathrm{U}(r=0.872)$. Correlation values between 0.600 and 0.700 were observed for Sc, Co, In, and W. A correlation value of 0.597 was found for Cd. Finally, considering Ga, As, Y, and Ba elements, correlation values lower than 0.420 were found.

In conclusion, distinct effects among bentonites were observed, indicating the importance of their physical and chemical characteristics on extraction phenomena, thus suggesting the need for more information about the trademark products. The wide diversity in the composition of wines (especially with respect to mineral, protein, and polysaccharide contents) is an additional influencing factor on bentonite elemental release.

The cation exchange capacity of bentonites is not significantly affected by the $\mathrm{pH}$ range studied. As previously mentioned, the negative charge resultant from isomorphic substitutions in smectites is constant and not affected by $\mathrm{pH}$ variation. However, the surface charge is slightly variable in the studied $\mathrm{pH}$ range. Thus, at low $\mathrm{pH}$ values, the development of some positive charge begins, while at high $\mathrm{pH}$ values, the negative charge is more intense. In fact, the protein adsorption process is influenced by the $\mathrm{pH}$ value, which can also change the structural conformation and the electric charge of proteins. A significant increase in adsorption capacity at $\mathrm{pH} 3.8$ was observed by Blade and Boulton (10).

It is known that, at lower $\mathrm{pH}$ values, more protons are available in solution. Additionally, as already stated, there is a strong preference for hydrogen adsorption. Therefore, at low $\mathrm{pH}$ values, the adsorption extent of competitor cations increases.

Elemental content in wines treated with bentonite was significantly affected by the $\mathrm{pH}$ value (2.94-3.58 range) (Table 4), which is in disagreement with observations reported by Nicolini et al. (3). Most of the elements presented the highest concentration at $\mathrm{pH}$ 2.94. Concerning some elements contained in the crystalline structure, such as Al, this tendency could be in part related to structure degradation, which could occur at these low $\mathrm{pH}$ levels. On the other hand, at highest $\mathrm{pH}$ value, some losses by insolubleness and precipitation may occur.

It should be stressed that the results are based on average values obtained from seven modalities (control wine and bentonite treated wines) at the same $\mathrm{pH}$. In fact, as shown in Table 4, interaction between bentonite and $\mathrm{pH}$ was observed. Not all the bentonites showed the highest release at the same $\mathrm{pH}$ value. For instance, at $\mathrm{pH} 3.32$, the $\mathrm{B} 9$ and $\mathrm{B} 1$ samples showed the lowest and the highest $\mathrm{Al}$ release, respectively. On the other hand, in some cases, the $\mathrm{pH}$ value had no effect on element release, such as Al release from the B3.

Finally, these results suggest the need for a better understanding of how $\mathrm{pH}$ affects the elemental release process and further research is desirable.

\section{ACKNOWLEDGMENT}

We thank Cristina Matos for manuscript revision and AEB Bioquímica Portuguesa, S.A., Ecofiltra, Lda, Meller \& Essink, Lda, Proenol, Lda, and Soeno, Lda, for providing the bentonite samples.

Sofia Catarino acknowledges the doctoral grant BD/17237/2004 and the postdoctoral grant BPD/34298/2007 of FCT (Science and Technical Foundation) from Portugal.

\section{LITERATURE CITED}

(1) Enkelmann, R. Migration of heavy metals from bentonites to wine.1. Note: Bentonites. Dtsch. Lebensm.-Rundsch. 1988, 84, $243-247$
(2) Jakubowski, N.; Brandt, R.; Stuewer, D.; Eschnauer, H. R.; Görtges, S. Analysis of wines by ICP-MS: Is the pattern of the rare earth elements a reliable fingerprint for the provenance. Fresenius J. Anal. Chem. 1999, 364, 424-428.

(3) Nicolini, G.; Larcher, R.; Pangrazzi, P.; Bontempo, L. Changes in the contents of micro- and trace elements in wine due to winemaking treatments. Vitis 2004, 43 (1), 41-45.

(4) Maujean, A. Proprieties physico-chimiques des bentonites: applications oenologiques. R. F. Oenol. 1993, 33 (143), 43-53.

(5) Bentonites; OIV Resolution OENO 11/2003; Office International de la Vigne et du Vin: Paris, 2003; http://www.oiv.int/.

(6) Brindley, G. W. Order-disorder in clay mineral structures. In Crystal Structures of Clay Minerals and their X-Ray Identification; Brindley, G. W., Brown, G., Eds.; Mineralogical Society: London, 1984, no 5, pp 125-195.

(7) Bailey, S. W. Summary and recommendations of AIPEA nomenclature committee. Clay. Clay Miner. 1980, 28, 73-78.

(8) Greenland, D. J.; Mott, C. J. B. Surfaces of soil particles. In The Chemistry of Soil Constituents. Greenland, D. J., Hayes, M. H. B., Eds.; John Wiley \& Sons: Chichester, 1978; pp 321-353.

(9) Marchal, R.; Barret, J.; Maujean, A. Relations entre les caractéristiques physico-chimiques d'une bentonite et son pouvoir d'adsorption. J. Int. Sci. Vigne Vin 1995, 29 (1), 27-42.

(10) Blade, W. R.; Boulton, R. Adsorption of protein by bentonite in a model wine solution. Am. J. Enol. Vitic. 1988, 39 (3), 193199.

(11) Gougeon, R. D.; Soulard, M.; Miehé-Brendlé, J.; Chézeau, J -M.; Le Dred, R.; Jeandet, P.; Marchal, R. Analysis of two bentonites of enological interest before and after commercial activation by solid $\mathrm{Na}_{2} \mathrm{CO}_{3}$. J. Agric. Food Chem. 2003, 51, 4096-4100.

(12) Gorinstein, S.; Goldblum, A.; Kitov, S.; Deutsch, J.; Loinger, C.; Cohen, S.; Tabakman, H.; Stiller, A.; Zykerman, A. The relationship between metals, polyphenols, nitrogenous substances and treatment of red and white wines. Am. J. Enol. Vitic. 1984, 35, 9-15.

(13) Barón, R.; Mayen, M.; Merida, J.; Medina, M. Changes in phenolic compounds and colour in pale Sherry wines subjected to fining treatments. Z. Lebensm.-Unters. Forsch. A 1997, 205, 474-478.

(14) Machado-Nunes, M.; Laureano, O.; Ricardo-da-Silva, J. M. Influência do tipo de cola (caseína e bentonite) e da metodologia de aplicação nas características físico-químicas e sensoriais do vinho branco. Ciência Téc. Vitiv. 1998, 13 (1-2), 7-28.

(15) Marchal, R.; Weingartner, S.; Voisin, C.; Jeandet, Ph.; Chatelain, F. Use of mathematical laws for optimizing the doses of swelled and dry bentonite during the fining of white wines. Part I: Clarification and colloidal stability. J. Int. Sci. Vigne Vin 2002, 36 (3), 169-176.

(16) Gössinger, M.; Schödl, H.; Steidl, R.; Meier, W. Comparison of commercial must and wine bentonites. Mitt. Klosterneuburg 1997, 47 (1-2), 1-7.

(17) Catarino, S.; Soares, J.; Curvelo-Garcia, A. S.; Bruno de Sousa, R. Implicações da utilização de bentonites sobre a fracção mineral de vinhos: potássio, sódio, cálcio, alumínio e chumbo. Efeito do pH. Ciência Téc. Vitiv. 2004, 19 (1), 29-45.

(18) Lemperle, E.; Kerner, E. Influence of fermentation and finishing on the ash content of wines. Weinwirtschaft-Technik 1988, 124 (8), 19-21.

(19) Gómez, M. M. C.; Brandt, R.; Jakubowski, N.; Anderson, J. T. Changes of the metal composition in german white wines through the winemaking process. A study of 63 elements by inductively coupled plasma mass spectrometry. J. Agric. Food Chem. 2004, 52, 2953-2961.

(20) Colagrande, O.; Griselli, F.; Del Re, A. A. Etude des phenomenes déchange lors de l'emploi des bentonites oenologiques. I - Les exchanges de sodium et de proline. Conn. Vigne Vin 1973, 2, 93-106.

(21) Sudraud, P.; Sudraud, F.; Gaye, J. Observations sur la composition et le contrôle d'efficacite des bentonites. R. F. Oenol. 1985, 25 (97), 21-24.

(22) Poinsaut, P.; Hardy, G. Bentonites. Analyses et comportements des bentonites. R. F. Oenol. 1995, 21 (76), 17-21. 
(23) Mihucz, V. G.; Done, C. J.; Tatár, E.; Virág, I.; Záray, G.; Baiulescu, E. G. Influence of different bentonites on the rare earth element concentrations of clarified Romanian wines. Talanta 2006, 70, 984-990.

(24) Mihaljevic, M.; Ettler, V.; Hradil, D.; Sebek, O.; Strnad, L. Dissolution of bentonite and release of rare earth elements at different solid/liquid ratios in a simulated wine purification process. Appl. Clay Sci. 2006, 31, 36-46.

(25) Póvoas, I.; Barral, M. F. Métodos de Análise de Solos. Série de Ciências Agrárias, Instituto de Investigação Científica Tropical. Secretaria de Estado da Ciência e Tecnologia: Lisboa. 1992.

(26) Catarino, S.; Curvelo-Garcia, A. S.; Bruno de Sousa, R. Measurements of contaminant elements of wines by inductively coupled plasma mass spectrometry: a comparison of two calibration approaches. Talanta 2006, 70, 1073-1080.

(27) Catarino, S.; Pinto, D.; Curvelo-Garcia, A. S. Validation and comparison of analytical methods by flame atomic absorption spectrometry for determination of copper and iron in wines and brandies. Ciência Téc. Vitiv. 2003, 18 (2), 65-76.

(28) Catarino, S.; Curvelo-Garcia, A. S.; Bruno de Sousa, R. Determination of aluminum in wine by graphite furnace AAS: validation of analytical method. Atom. Spectrosc. 2002, 23 (6), 196-200.
(29) Catarino, S.; Madeira, M.; Monteiro, F.; Curvelo-Garcia, A.S.; Bruno de Sousa, R. Release of contaminant elements from bentonites to wine: a contribution to achieve a test solution. Cienc. Tecnol. Vitic. 2006, 21 (1), 17-31.

(30) OIV Compendium of International Methods of Analysis of Wine and Musts; Office International de la Vigne et du Vin: Paris, 2007; http://www.oiv.int/.

(31) Kayabali, K.; Kezer, H. Testing the ability of bentonite-amended natural zeolite (clinoptinolite) to remove heavy metals from liquid waste. Environ. Geol. 1998, 34 (2/3), 95-102.

(32) Pellerin, P.; O’Neill, M. A.; Pierre, C.; Cabanis, M -T.; Darvill, A. G.; Albersheim, P.; Moutounet, M. Complexation du plomb dans les vins par les dimères de rhamnogalacturonane II, un polysaccharide pectique du raisin. J. Int. Sci. Vigne Vin 1997, 31 (1), 33-41.

(33) Ribéreau-Gayon, P.; Glories, Y.; Maujean, A.; Dubourdieu, D. The Chemistry of Wine Stabilization and Treatments. In Handbook of Enology; John Wiley \& Sons Lta: Paris, 2000; Vol 2.

Received for review July 5, 2007. Revised manuscript received October 24, 2007. Accepted October 24, 2007.

JF0720180 